\title{
ZÖLDSÉG-GYÜMÖLCS FOGYASZTÁS VIZSGÁLATA A MAGYAR FOGYASZTÓK KÖRÉBEN
}

\author{
- भी० - \\ EXAMINING OF FRUIT AND VEGETABLE CONSUMPTION \\ AMONG THE HUNGARIAN CONSUMERS \\ SZABÓ, IMOLA
LEHOTA, JÓZSEF \\ ?ac- \\ Szent István Egyetem, Gazdálkodás és Szervezéstudományok Doktori Iskola \\ (Szent István University, Doctoral School of Management and Business Administration) \\ H-2100 Gödöllő, Páter Károly u. 1. \\ e-mail: 1.szabo.imola@gmail.com
}

\begin{abstract}
\& The importance of fruit and vegetable consumption is emphasized by promotions, recommendations, and domestic and foreign researches. According to the results of Hungarian research, consumers with high education and high income are the fastest to commit to a healthy lifestyle (of which regular consumption of fruit and vegetables is an integral part). The present study examines fruit and vegetable consumption through focus group interviews examining two distinct segments; full-time undergraduate students as well as full-time adults. The reason for choosing the two segments was based on the literature, according to which lifestyle research shows that the supportive family financial background of students helps to make this segment more health-conscious, while full-time adults with higher education and income are also more health-conscious consumers. Based on the results of interviews with six groups - three with students and three with full-time adults - it can be stated that among the participants the reasons for consuming fruit and vegetables are health awareness, and in many cases the family pattern is a determining, moreover important aspect that vegetables and fruits are very much loved. However, despite their commitment to a healthy lifestyle and fruit and vegetable, most of them have never heard of fruit and vegetable promotions. As a result of the focus group research, it can also be observed that income is a determining factor, especially in the face of rising prices. In addition to consumption patterns, the research also addressed the issue of branding, the results of which suggest that geographical indications are still more important than the creation of a stand-alone brand name.
\end{abstract}

KuLCSSZAVAK: zöldség-gyümölcs fogyasztás, fókuszcsoport, jövedelem, iskolai végzettség

JEL-KóDOK (JEL CODES): I12, P46

DOI: https://doi.org/10.20494/TM/7/2/6
KEYWORDs: fruit and vegetable consumption, focus group analysis, income, education 


\section{BEVEZETÉS - INTRODUCTION}

TAMUS (1998) doktori értekezésében a hazai gyümölcsfogyasztókat tipizálta. Kutatás során öt különböző csoportra bontotta a fogyasztókat. A „minőségközpontú” fogyasztóknak a gyümölcsfogyasztásuk során a legfontosabb a termék minősége, melyet a védjegy garantál. Ezen csoport tagjai a jó minőségủ termékért hajlandóak többet fizetni, ha úgy érzik, ez egyben a biztonságot is jelenti. A „konzervatív” fogyasztók számára „a hazai termék jó minőségébe vetett hit" fontos értéket képvisel vásárlásaik során. Az „igényesen takarékos” csoport tagjainak fontos, hogy a gyümölcsfogyasztásnak ne legyenek táplálkozás-élettani kockázati tényezői. Ók azok, akik az ár, a biztonság és az élvezeti értékek közötti optimalizációra törekszenek gyümölcsvásárláskor. A „Szerény kisember” gyümölcsfogyasztását jövedelme korlátozza. A gyümölcsfogyasztást és a jó minőséget fontosnak tartja, de anyagi helyzete miatt az olcsóság nyer prioritást.

A „flegmatikus” fogyasztók nem tulajdonítanak jelentőséget a gyümölcsfogyasztás fontosságának, közömbösek a gyümölcsök pozitív élettani hatásai iránt, nem fontos számukra sem a hazai termék, sem pedig a védjegy alkalmazása. Ahogy a csoport neve is sugallja, közömbösek, flegmatikusak e kérdéskörrel kapcsolatban.

A magyar fogyasztók a gyümölcsöket és a zöldségeket tekintik a legegészségesebb élelmiszernek, melyet szeretnek és szívesen is fogyasztanak (SZAKÁLY et al., 2013; GFK, 2019), sajnos azonban nem akkora mértékben, hogy azt az ajánlások megfogalmazzák. A friss zöldség-gyümölcs fogyasztás minimum értékét napi 400 grammban határozta meg a WHO (2019) több mint 15 évvel ezelőtt. A magyar lakosság fogyasztási szintje nem éri el ezt az értéket. A KSH (2018) adatai szerint 2018-ban a burgonya nélküli zöldség-gyümölcs fogyasztás egy főre eső nap mértéke 299 gramm volt, azonban a gyümölcskészítmények és a tartósított zöldség, zöldségkészítmények nélkül mindöszsze 266 gramm. Megjegyzendő, 2010-ben még ennél is alacsonyabb volt a fogyasztás mértéke, a burgonya nélküli érték 235 gramm, a gyümölcskészítmények és a tartósított zöldség, zöldségkészítmények nélkül pedig 217 gramm.
Magyarországon is sok ajánlás és népszerúsítő program hívja fel a figyelmet e két termék magasabb szinten történő fogyasztásának fontosságára. Leginkább a magyar lakosság ár- és ízérzékenység meghatározó e problémakörben, ám nemcsak hazánkban tapasztalható az alacsony fogyasztási szint. Azonban számos faktor mentén megfigyelhető, hogy a társadalom bizonyos szegmensei kifejezetten odafigyelnek az egészséges étkezésre.

A Tárki (2008) kutatása alapján a társadalmi rétegződés csúcsán („felső plusz”, „felső klasszik”), és felső-közép részein („befutott értelmiség”, „hedonista fiatalok”) helyezkednek el azok, akiknek lehetőségük van kimagasló fogyasztásra, beleértve a minőségi, változatos élelmiszerfogyasztást. Ezen klaszterekbe tartozók jellemzóen magas végzettséggel, és magas jövedelemmel rendelkeznek. Sok köztük a tehetős családi hátérrel rendelkező egyetemista, a gyorsan befutott fiatal, valamint a magasabb jövedelemmel rendelkező értelmiségi. A csoportokban sok alkalmazott is található, tehát nem feltétlenül csak a felsővezetôkre jellemző a magas fogyasztási szint. Az alsóbb rétegekben már jellemzően alacsonyabb jövedelmú és végzettségű emberek alkotják a klasztereket, mely okok kihatnak a fogyasztási lehetőségeikre is, beleértve az élelmiszerfogyasztást is (KELLER, 2008).

Az Osztálylétszám 2014 GfK-MTA közös kutatása is hasonló képet mutat a tekintetben, hogy a társadalom felsőrétegeibe a magas végzettségü és keresetü emberek kerülnek be. Az „elit” mindösszesen 2\%-ot képviselt ekkor, a „felső-közép” 10,5\%-ot, a „feltörekvő fiatalok” 6\%-ot, ez utóbbiak sokszor még a szülői támogatás kedvezményezettjei. A felsőbb rétegek tagjai többségében Budapesten vagy vidéki nagyvárosokban élnek A „vidéki értelmiség, (7\%) sok szempontból hasonló tulajdonságokkal és fogyasztási lehetőségekkel bír, mint a felsőbb rétegek, csak korlátozottabb mértékben. A társadalom alsóbb rétegeiben az alacsonyabb jövedelmi és végzettségi szint miatt a fogyasztási lehetőségek is korlátozottabbak (KOZÁK és VERES, 2014; RÓBERT, 2014).

A 2008-as Tárki kutatásban a négy felsőbb réteg a társadalom 37\%-át jelentette. A 2014-es GfK-MTA kutatás négy felsőbb rétege 25,5\%-át jelentette. Ennek a visszaesésnek egy jelentős 
oka lehetett a 2008-as gazdasági világválság, ami a 2014-es kutatásra hatással volt.

TÖRÖCSIK és munkatársai által végzett 2018-as életstílus kutatás egészen új életképet fest a magyar társadalomról. E kutatás alapján a legfelsőbb, illetve felsőbb-közép rétegeket képzik a „karrierépítők” (4,8\%), a ,jól élő fiatalok” (15,3\%), az „életélvezők” (16\%), illetve a „biztonságra törekvők” (8,1\%). Ez a négy klaszter összesen a társadalom 44,2\%-át jelentik. A GfK-MTA kutatáshoz képest ez jelentős növekedést mutat, ami jelentheti azt is, hogy egyre többen élnek jobb körülmények között. Ezt támasztják alá a KSH adatai is. A 2008-as gazdasági világválság igencsak visszavetette a háztartások jövedelmi helyzetét is, mely után 2010-ben némi remény látszódott, és a reáljövedelmek enyhén emelkedtek, ám ez 2012-ben ismét törést szenvedett. 2013-ban a magánháztartásokban $1,2 \%$ reáljövedelem emelkedés volt megfigyelhető (KSH, 2013). A KSH „A háztartások életszínvonala” kiadványában a 2014-es évtől viszont folyamatosan a magyar háztartások életszínvonalának javulásáról számol be, mely a jövedelmi helyzetek pozitív elmozdulása miatt a fogyasztás szerkezetére is kihat minőségi és mennyiségi értelemben is (KSH, 2014;2015;2016;2017;2018). E kutatás eredményei is azt mutatták, hogy a társadalom felső rétegeiben ott vannak az egyetemisták, illetve azok szülei, valamint a fiatal és gyorsan befutott értelmiség. Szintén felülreprezentált a felsőfokú végzettséggel és magasabb jövedelmi szinttel rendelkezők aránya. Fogyasztásuk változatos és sokoldalú, illetve megjelenik az egészség és a tudatosság fontossága is (TÖRÖCSIK et al., 2019).

VETÓNÉ MÓZNER (2014) kutatásában reprezentatív kutatások eredményeit elemezte, többek közt klaszteranalízis módszerével, mellyel arra a következtetésre jutott, hogy a zöldség-gyümölcs és tejfogyasztó klaszterbe leginkább a fiatalabb korosztály tartozik (2029, valamint 30-39 év közöttiek), a klaszteren belül magas a tanulók aránya. Ók azok, akik nagyon környezettudatosak, és életmódjukat tekintve is jellemző rájuk a tudatosság.

MALOTA és munkatársai (2019) kutatásukban arra mutattak rá, hogy az egészségtudatosság fóleg a fiatalokra, a magasabb végzettségűek, a magasabb jövedelműek, a nagyvárosokban élő fogyasztókra jellemző, és inkább a nőkre. Reprezentatív felmérésükben a válaszadók a zöldséget és a gyümölcsöt említették, mint a legegészségesebb ételek, illetve az egészséges étkezés legfontosabb komponenseinek. Azonban a válaszadók szerint az egészséges ételek általában drágák.

Ahogy a kutatók is rámutatnak, a jövedelem és a végzettség rendkívül meghatározó az egészséges élet(mód) megválasztásakor.

A hazai LOHAS szegmens képviselői is hasonló tulajdonsággal bírnak, inkább nagyobb városokban lakó, fóleg magasan képzett, magas jövedelemmel rendelkező nők azok, akik életmódját az egészség és a fenntarthatóság jellemzi. Ez az életstílus inkább a fiatalabb korosztályra jellemzőbb (RÁCZ, 2013; LEHOTA et al., 2014; SZAKÁLY et al., 2015).

SZAKÁLY és munkatársai kutatása (2014) rámutatott arra, hogyan kapcsolódnak össze a személyes értékek az egészségtudatossággal, az egészséges életre való áttérés hajlandóságával. LOV értéklistát alkalmazva, a faktoranalízis eredményeként az „értékorientáltak” mutatták a legnagyobb mértékben az egészségtudatosság jeleit, valamint az egészséges életmódra való áttérési hajlandóságot. Az „értékorientáltak” csoportjában a nemek kiegyenlítettek, a fiatal korosztály felülreprezentált épp úgy, mint a diplomások. Azonban az érettségizettek száma is magas. Az átlaghoz képest magasabb jövedelemmel rendelkeznek, és majdnem felük a fóvárosban vagy megyei jogú városban él.

A már említett KSH „A háztartások életszínvonala" kiadványokban is jól látható, hogy a magasabb iskolai végzettséggel rendelkezők, a fővárosban vagy a megyei jogú városokban élők magasabb jövedelemmel rendelkeznek.

Ahogy HOFMEISTER-TÓTH (2014) írja, a foglalkozás, a pozíció a társadalmi hovatartozást is sokszor megmutatja, rétegképző, valamint szorosan összefügg az egyén anyagi-egzisztenciális helyzetével. Mivel a társadalmi rétegződés az életstílus meghatározó elemei, ezért hatással van a fogyasztásra is. Bár a társadalmi rétegződést és ezáltal az életstílust nemcsak a jövedelmi viszonyok határozzák meg, befolyásoló szerepét nem lehet figyelmen kívül hagyni.

Nemzetközi vizsgálatok eredményeit tekintve szintén megfigyelhető, hogy van ösz- 
szefüggés az iskolai végzettség, a jövedelem, a korosztály és az egészséges életmód iránt való elköteleződés között. A GfK Kutatóintézet a német háztartásokban végzett kutatása is kimutatta, hogy az egészségesebb életmódot folytatók csoportjára jellemző a magas jövedelem és a magas iskolai végzettség (THIELE et al., 2017). ALKERWI és munkatársai (2015) luxemburgi kutatása is arra az eredményre jutott, hogy számos demográfiai faktor (kor, nem, iskolai végzettség) pozitív korrelációt mutat az egészséges táplálkozással kapcsolatban. FEINSTEIN és munkatársai (2006) részletes tanulmányukban bizonyítják, hogy az oktatás, az iskolai végzettség, a jövedelem nagyon fontos tényező az egészséges életmód iránti elköteleződésben.

Jelen tanulmányunkban fókuszcsoportos kutatás módszerével kerestük a válaszokat arra, hogy melyek a rendszeres zöldség-gyümölcs fogyasztás fó okai, hogyan vélekednek a magyar fogyasztók a hazai és az import zöldségekről, gyümölcsökről, ismerik-e a zöldség-gyümölcs fogyasztási promóciókat, valamint mit gondolnak a márkázás szükségességéről.

\section{ANYAg ÉS MÓDSZER - MATERIAL} AND METHOD

Jelen tanulmány elkészítése fókuszcsoportos kutatás alkalmazásával valósult meg. Olyan fogyasztók kiválasztásán volt a hangsúly, akik minden nap vagy legalább hetente többször fogyasztanak zöldséget és gyümölcsöt. A toborzás részben egy budapesti székhelyű és egy Pest megyei székhelyű egyetem polgárai körében történt, valamint hólabdaszerü megkeresés módszerével. A kiválasztott résztvevők két nagy csoportba lettek sorolva „főállásukat” tekintve; nappali tagozatos felsőoktatásban résztvevő hallgatók, illetve fóállásban dolgozó felnőtt emberek. Ezáltal életkor szerint is elkülönült egymástól a két csoport, így a korosztálybeli különbségekből és az ebből (is) adódó eltérő napi rutin miatti eltérések felszínre hozása is lehetségessé vált. Összesen hat fókuszcsoporttal sikerült kutatást végezni, három csoportban nappali tagozatos hallgatók voltak, a másik háromban pedig fóállásban dolgozók. A csoportok létszáma eltérő volt, általában 8-12 fő közt, de - a visszamondások miatt - volt néhány kisebb létszámú csoport is.

A fókuszcsoportok általában 8-12 főből állnak, de manapság egyre többször alkalmaznak kisebb csoportokat 5-7 fővel, mely még bensőségesebb megnyilvánulásokhoz vezethet (LEHOTA, 2001; MALHOTRA, 2009). A legújabb kutatások szerint a fókuszcsoportok állhatnak 8-10 fóből, illetve a mini-csoportok 4-6 fóből (GYULAVÁRI et al., 2014). Fókuszcsoportos vizsgálatok során általában 2-3 csoportot alkalmaznak (LEHOTA, 2001). A kutatás során mindkét vizsgált kategóriában 3-3 csoportos interjú került lebonyolításra.

A fókuszcsoportok megtartására 2019. október és 2019. december között került sor. Öszszesen 43 fő vett részt a kutatásban.

$\mathrm{Az}$ eredmények bemutatása nem csoportonként, hanem főállásuk tekintetében, azaz külön a felsőoktatási hallgatókat, illetve a fóállásban dolgozókat, de a kategóriánként 3-3 csoportot egybevonva kerül értékelésre. Az eredmények prezentálásában a két fő kategória demográfiai adatai is bemutatásra kerülnek, hiszen ezekből is következtetni lehet számos ok-okozati tényezőre, illetve további kutatási kérdések támpontjai lehetnek.

\section{EREDMÉNYEK - RESUltS}

\subsection{Nappali tagozatos felsőoktatásban tanuló hallgatók - Full-Time Students in Higher Education}

A három csoport összesített demográfiai adataiból a következő elemzési adatok állnak rendelkezésünkre. A nappali tagozatos felsőoktatásban tanuló hallgatók három csoportjában összesen 25 fő vett részt a kutatásban, ebből 16 férfi és 9 nő. Életkorukat tekintve 24 fő 18-24 év közötti, 1 fő 25-35 év közötti. Nappali tagozatos státuszokból eredően életkorukat tekintve homogén csoport. A csoport fele budapesti, fele vidéki lakhelyü. Szabadon elkölthető jövedelmük (lakhatási, megélhetési költségeken túl) havonta a résztvevők 40\%-ának 50000 Ft fölötti, 12\%-ának 40 001-50 000 Ft közötti, amiből jól látszik, hogy a csoport több mint 50\%-a minimum 40 ooo Ft havi szabadon elkölthető jövedelemmel rendelkezik. A további 
megoszlások: 36\% 20 001-30 ooo Ft közötti, 8\% 10 001-20 000 Ft közötti, 4\% pedig 0-10 ooo Ft közötti (1. ábra).

A csoport $2 / 3$-a fogyaszt zöldséget és gyümölcsöt hetente többször, de nem minden nap, 1/3-uk azonban minden nap. Érdekességként megjegyzendő, hogy a nemek aránya azok között, akik minden nap fogyasztanak zöldséget és gyümölcs, fele-fele volt. A két vizsgált csoport zöldség-gyümölcs fogyasztási szokásait a 2. ábra mutatja.

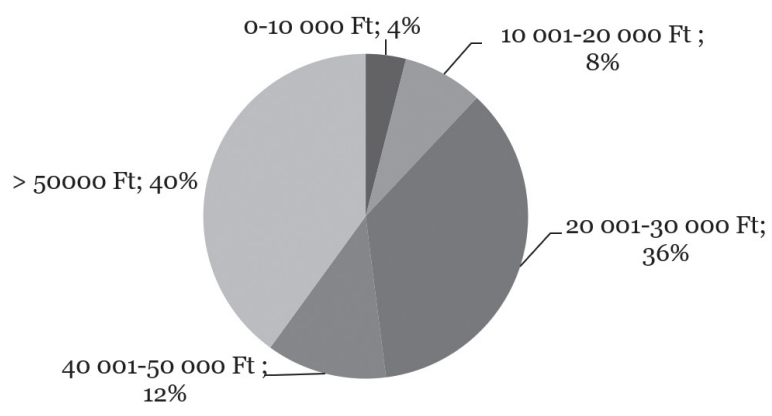

1. ÁBRA

A résztvevő egyetemi hallgatók havi szabadon elkölthető jövedelme

FIG. 1 (Monthly Free Disposable Income of Participating University Students)

Forrás (Source): Saját szerkesztés, 2019 (Own compilation, 2019)

2. ÁBRA

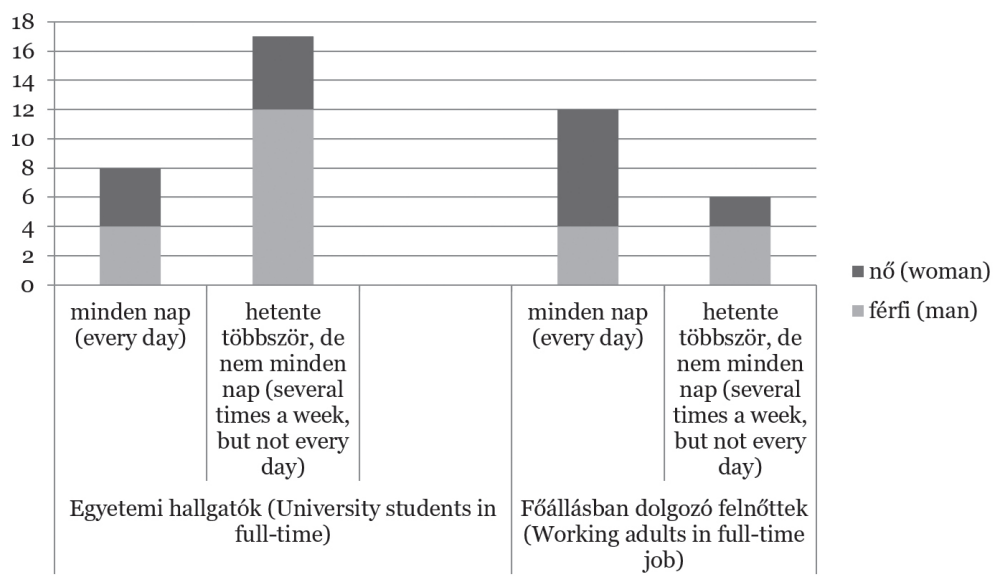

FIG. 2

A résztvevők zöldség-gyümöles fogyasztási szokásai, fó (Participants' Fruit and Vegetable Consumption Habits, capita)

Forrás (Source): Saját szerkesztés, 2019 (Own compilation, 2019)

Arra a kérdésre, hogy mi az oka annak, hogy zöldséget és gyümölcsöt ilyen rendszerességgel fogyasztanak, a leggyakoribb válaszok - az említések gyakorisága alapján - a következők voltak:

- családi minták alapján,

- nagyon szeretik a zöldséget és a gyümölcsöt,
- egészséges,

- étkezés része,

- egészséges táplálkozás része,

- jól esik a szendvics mellé,

- sportolás után jól esik.

A 3. ábra jeleníti meg a kutatásban résztvevők válaszaiból kialakult szófelhőket, melyekből kitűnik, hogy mindkét vizsgált csoportnál 
a két termék szeretete fontos szerepet játszik döntésükben.

A résztvevő hallgatók egyöntetűen igennel válaszoltak arra a kérdésre, hogy hisznek-e a zöldség-gyümölcs szervezetre gyakorolt jótékony hatásában. A résztvevő hallgatók esetében megfigyelhető, hogy többségüknél a család is hasonlóan sok zöldséget és gyümölcsöt fogyaszt, mint ők, csak néhányan mondták, hogy a család valamely tagja kevesebbet vagy alig fogyaszt. Azon résztvevők, akik nem minden nap fogyasztanak zöldséget és gyümölcsöt, azzal indokolták az egy-egy nap kimaradást, hogy akkor túlzottan rohannak, nincs otthon (elfogyott), nem elég friss, és már nem kívánja, nem jut eszébe, vagy csak valamiért kimarad. A résztvevők fele nyilatkozta azt, hogy amely napokon nem fogyaszt zöldséget és gyümölcsöt, akkor érzi a hiányát, a másik fele nem.

Az egyre emelkedő zöldség-gyümölcs árakra a 25 hallgatóból 17 felfigyelt, viszont csak 7 főt befolyásol vásárlási szokásaiban, ők megvárják az akciókat, inkább az akciós termékeket veszik. Egy fő nem érzékelte az árnövekedést. Öt résztvevő úgy nyilatkozott, hogy ők nem figyelik az árakat, ennek egyik oka az, hogy nem ők vásárolnak, de van, akit kevésbé érdekel, hogy mennyibe kerül, ha jó a minősége, vagy ha épp azt a terméket kívánja. Három hallgató úgy nyilatkozott, hogy ők otthon termelnek, így az ár kevésbé van hatással fogyasztói szokásaikra, nem is figyelik, bár közülük egy fő úgy nyilatkozott, hogy érzi az áremelkedést.

A szezonális termékek fogyasztásával kapcsolatban megoszlottak a vélemények, általánosságban elmondható, hogy a résztvevők a szezonális zöldséget, gyümölcsöt preferálják, ha van, de ha nincs, akkor a nem szezonális is megfelelő. A hazai és az import termékek esetében is hasonló állásponton voltak. A 25 fóből 1 fó nyilatkozott úgy, hogy csak hazai terméket vásárol, 2 fó inkább az importot részesíti előnyben, 2 főnek mindegy, hogy honnan származik a zöldség-gyümölcs, 5 fő pedig nem is figyeli a származást. Tizenöt fő nyilatkozta, hogy ha van, akkor a hazait preferálják, de ha nincs, akkor az importot is fogyasztják. Ha ehhez a 15 főhöz hozzávesszük azokat, akik nem figyelik a termék származását, illetve akiknek mindegy, hogy honnan jött a termék, akkor a 25 fóből 22 fogyaszt mind import mind pedig hazai zöldséget és gyümölcsöt. Akik a hazait részesítik előnyben, jobb ízűnek és minőségűnek gondolják a magyar terméket, és hajlandóak is akár többet fizetni érte. Szerintük a magyar termékek vásárlásával a magyar gazdaságot is segítjük, és ez fontos számukra. Néhány hallgató úgy vélekedett, hogy az importnál nem tudni, mivel kezelték, ezért nem gondolja jónak annak fogyasztását.

Arra a kérdésre, hogy szükséges-e márkázni a zöldségeket, gyümölcsöket, $3 / 4$ részben nemmel válaszoltak. Akik szerint szükséges, ők a márkázásban a megbízhatóságot, a minőséget találták fontosnak. Ezzel szemben a résztvevők többsége szerint a földrajzi jelzés feltűntetése (pl. hevesi dinnye, makói hagyma) fontos és szükséges, mert pozitív sugallata lenne, minőséget, megbízhatóságot jelent.

Szabad asszociáció keretében a résztvevőket arra kértem, mondják el, mely termék lenne igazán a zöldség-gyümölcs konkurense, tehát ha eléjük tennének zöldséget, gyümölcsöt és egy másik terméket, mi lenne az a másik, amit választanának szemben a zöldség-gyümölccsel. Sokféle válasz született, például; édesség (főleg csokoládé), nassolnivaló, hús, sajt, meleg étel, pizza, sajtburger. A meleg étel kivételével legfóbb ok, hogy a választott étel kulináris élvezet, íze sokkal jobb, mint a zöldségé vagy a gyümölcsé. Megfigyelhető volt még, hogy a fiatalembereknél a „húst hússal” étkezési szokás dominál, míg a hölgyeknél az édesszájúság. A meleg étel tekintetétben pedig a szükség / hasznosság / fiziológiai szükséglet (hogy ne legyenek éhesek) döntött.

Sajnálatos módon a résztvevő hallgatók 92\%-a nem hallott a zöldség-gyümölcs fogyasztási promóciókról, és nem ismerik a fogyasztási ajánlásokat. 

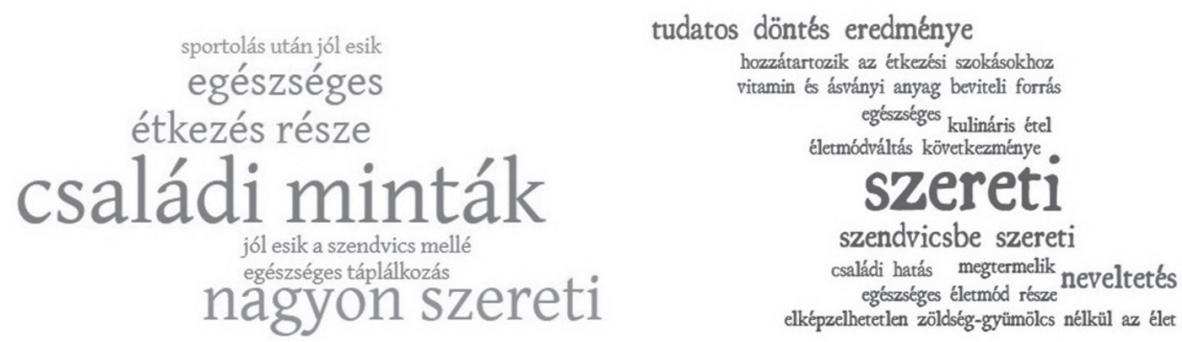

FIG. 3

3. ÁBRA

A nappali tagozatos egyetemi hallgatók és a foóllásban dolgozó felnőttek zöldség-gyümölcs fogyasztásainak fóbb okai

(Main Causes of Fruit and Vegetable Consumption by Full-Time University Students and Working Adults in Full-Time Job)

Forrás (Source): Saját szerkesztés, 2019 (Own compilation, 2019)

\subsection{Főállásban dolgozó felnőttek - Working Adults in Full-Time Job}

A három csoportban összesen 18 fó vett részt a kutatásban, ebből tíz nő és nyolc férfi, többségük budapesti lakosú. Beosztásukat tekintve egy fő már nem aktív/nyugdíjas, mindenki más alkalmazott. Heten egyetemi vagy főiskolai végzettséggel rendelkeznek, hatan középfokú végzettséggel, de munkájuk mellett már egyetemi tanulmányokat végeznek, öten középfokú végzettséggel rendelkeznek. Életkorukat tekintve heten 45-59 év közöttiek, öten 25-35 év közöttiek, négyen 36-44 év közöttiek, illetve egy-egy fó képviselte magát a 60-65 év közötti és 65+ év feletti korosztályból is. A 4. ábrán látható a jövedelmi viszonyok alakulása. A részvevők felének nettó havi keresete 200 001-300 ooo Ft közötti összeg, 12\%-uknak 100 000-200 000 Ft közötti, a csoport többi tagja ugyanolyan arányban jelölte meg a 300 001-400 000 Ft és a 400 001-500 000 Ft közötti sávot, illetve volt, aki erre a kérdésre nem adott választ. Az összehasonlíthatóság végett a KSH adatai szerint Magyarországon 2019 szeptemberében a nettó átlagkereset 239900 Ft volt (KSH, 2019). Az adatokból látszik, hogy a résztvevők többsége minimum átlagkereseti szinttel rendelkezik, illetve többen vannak, akik afölötti jövedelemmel.

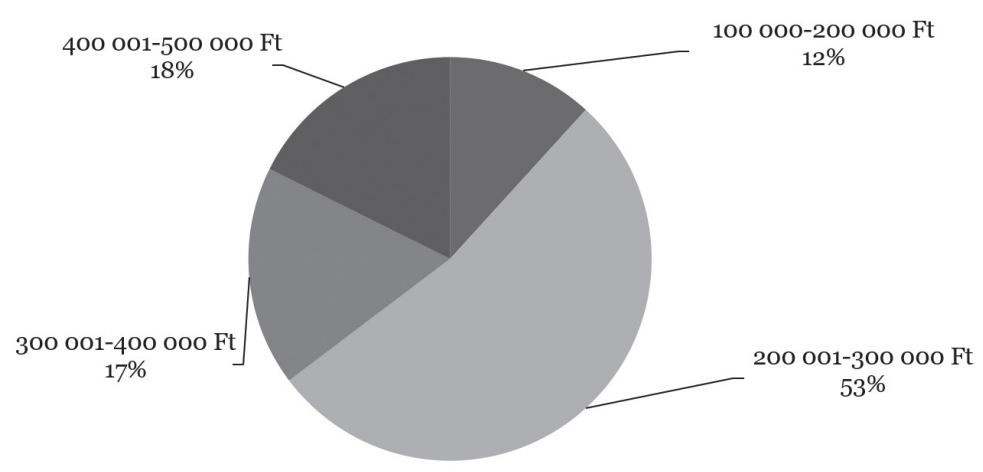

4. ÁBRA

A résztvevő fơállásban dolgozó felnőttek nettó havi jövedelme

FIG. 4 (Net Monthly Income of Participating Working Adults in Full-Time Job)

Forrás (Source): Saját szerkesztés, 2019 (Own compilation, 2019) 
Zöldség-gyümölcs fogyasztás tekintetében 12 fö nyilatkozott úgy, hogy minden nap fogyasztják, ebből kétszer annyi nő, mint férfi válaszolt így, 6 pedig hetente többször, de nem minden nap (lásd: második ábra).

A főállásban dolgozó felnőttek esetében az okok, amiért ilyen rendszerességgel fogyasztanak zöldséget és gyümölcsöt, a válaszok gyakorisága alapján a következők voltak:

- szeretik,

- családi hatás, neveltetés,

- tudatos döntés eredménye,

- szendvicsbe szeretik,

- egészséges,

- egészséges életmód része,

- hozzátartozik az étkezési szokásokhoz,

- vitamin és ásványi anyag beviteli forrás,

- elképzelhetetlen zöldség-gyümölcs nélkül az élet,

- életmódváltás következménye,

- megtermelik,

- kulináris ételnek (élvezetnek) tartja.

A zöldség-gyümölcs szervezetre gyakorolt jótékony hatásában a 18 résztvevő főből 15 hisz, 1 fö szerint van alapja, 1 fő nem foglalkozik vele, 1 fő pedig már nem hisz benne. A kérdéskörrel kapcsolatban többekben felmerült az is, hogy a ma kapható zöldségek és gyümölcsök már nem olyanok, mint régen voltak. Már nem olyan jó az ízük, mint régen volt, túl hamar megromlanak. A bizalom is megingott a két termék irányában. Bár abban biztosak, hogy jótékony a szervezetre nézve, de hogy ugyanolyan egészségesek-e, illetve ugyanannyi vitamint tartalmaznak-e mint régen, ebben már némi kétely merült fel. A résztvevők esetében jellemzően a család többi tagjai is hasonlóan sok zöldséget és gyümölcsöt fogyasztanak.

A zöldséget és a gyümölcsöt egyre drágábbnak érzik, mindösszesen 2 fő nem foglalkozik a termékek árával, mivel egyszemélyes háztartást vezetnek, így a kis mennyiség miatt megtehetik, hogy amit megkívánnak, megvegyék. A 16 főből 12 fő vásárlási döntését befolyásolja, 2 fó esetében termékfüggő, 2 fő esetében nem befolyásolja az áremelkedés a vásárlási döntésüket. Akiknek döntését befolyásolja, ők átgon- dolják, mit vesznek, nézik az akciókat, illetve többen kevesebb mennyiséget vásárolnak a növekvő árak miatt. Volt olyan résztvevő, akik szerint elrugaszkodtak az árak, és volt, akinél bizonyos zöldségek és gyümölcsök vásárlása ajándékszámba megy.

Azok, akik egy-egy nap valamilyen oknál fogva nem fogyasztanak gyümölcsöt (pl. nincs otthon, kimarad), általában nem érzik hiányát, bár ennek legfóbb oka, hogy nagyon ritkán fordul elő, hogy kimarad. Néhányan úgy nyilatkoztak, hogy azt a ritka kimaradást is megérzik, és hiányolják.

A három csoport összességében nem gondolja, hogy külön kéne vizsgálni az import vagy a hazai zöldség-gyümölcs vásárlását, hiszen egyre nehezebb megkülönböztetni, melyik az, és melyik nem (pl. az átcsomagolási botrányok miatt), mindkettőben csalódtak már, nem lehet kiküszöbölni, hogy ne fogyasszunk importot pl. a déligyümölcsök miatt, és az importban is van jó ízű, jó minőségű. Ettől függetlenül a hazait szeretik, ha tehetik, azt fogyasztják, de többen nyilatkoztak úgy, ha jó a minősége, mindegy, hogy honnan származik.

A márkázással kapcsolatos kérdésre a 18ból 14 egyértelműen nemmel válaszolt, 3 résztvevő szerint kell márkázni, míg 1 résztvevő szerint lehet, hogy jó márkázni, mert a márkanév minőséget jelent. Ezzel szemben a földrajzi jelzés feltüntetése pozitívan hat(na), minőséget jelentene. Néhányan úgy gondolták, inkább a termék fajtatípusa a fontos, nem az, hogy hol termesztik, illetve a termelő megnevezése is fontos lehet.

Fơtt étel, sajt, hús és a csokoládé tűnt a zöldség-gyümölcs legnagyobb versenytársának amellett, hogy a résztvevők fele nem cserélné le semmi másra a zöldséget és a gyümölcsöt.

A zöldség-gyümölcs fogyasztási promóciókról és a fogyasztási ajánlásokról a résztvevők több mint fele sosem hallott, három résztvevő egy alkalommal hallott róla, hárman pedig már hallottak róla. Egy résztvevő nyilatkozott úgy, hogy nem hallott a promóciókról, de az ajánlásoknak utána olvasott. 


\section{KöVETKEZTETÉSEK ÉS}

\section{JAVASLATOK - CONCLUSIONS AND \\ PROPOSALS}

Az eddigi kutatások, valamint a jelen kutatás is azt mutatja, hogy az egészséges életmód iránt elkötelezettek általában magasabb végzettséggel és magasabb jövedelemmel rendelkező fogyasztók, vagy azon egyetemisták, akiknek családi háttere lehetővé teszi, hogy mindezt megfelelő szinten finanszírozni tudják. Az egészséges táplálkozás egyik fő összetevője a zöldség-gyümölcs, melynek árai az elmúlt egykét évben igen jelentősen emelkedtek, így nem csoda, hogy az alacsonyabb jövedelmű családoknak, fogyasztóknak ez még nagyobb problémát jelent. A jelen kutatás arra enged következtetni, hogy a heti többszöri vagy napi szintü zöldség-gyümölcs fogyasztás - mely e termékek iránt megnyilvánuló elköteleződésként is értelmezhető - egyrészről egy tudatos választás, továbbá szerepet játszik benne a családi minta, azonban nem elhanyagolható fontosságú e termékek iránt érzett emocionális kötődés.

A kutatásban résztvevők $1 / 3-a$ nyilatkozta azt, hogy a rendszeres zöldség-gyümölcs fogyasztásának elsődleges és fő oka az, hogy szeretik e két termékkategóriát. Ez a fajta kötődés kutatási szempontból nagyon fontos, hiszen ez már nem azt jelenti, hogy csak azért fogyasztja, mert otthon így látta a felmenőitől, vagy mert úgy tudja, hogy ezen termékek fogyasztásával megőrizheti egészséget, hanem egyszerűen a zöldség-gyümölcs a kedvenc termékük. Az emocionális kötődés egy termékhez vagy termékkategóriához sokkal mélyebb és hosszú távon hatásosabb, mint egy eltanult, megtanult fogyasztási norma.

A kutatás arra is rávilágított, hogy - bár szakmai körökben a zöldség-gyümölcs márkázás témaköre egyre többször kerül napirendre - a kutatásban résztvevők többsége nem gondolja úgy, hogy szükség lenne külön brand-re, ámbár a fölrajzi jelzés feltüntetése (abban az esetben, ahol nem teszik meg) bizalmat, minőséget, megbízhatóságot jelentene.

A kutatás során a tudatosabb és elkötelezettebb fogyasztók között felmerült az a gondolat, hogy bár többségük egyértelműen hisz a zöldség-gyümölcs szervezetre gyakorolt jótékony hatásában, mégis néhányan úgy nyilatkoztak, hogy a ma kapható zöldségek és gyümölcsök sem ízre, sem állagra nem olyanok, mint a régiek voltak, és vitamin tartalmuk is megkérdőjeleződött. Ez az eredmény azért sajnálatos, mert ha már az elkötelezettebb fogyasztók körében is felmerülnek ilyen kételyek, akkor azok, akik csak ritkán fogyasztanak zöldséget és gyümölcsöt, vajon miként vélekedhetnek a témakörről. Szintén elgondolkodtató az az eredmény, hogy a résztvevők többsége sosem hallott még a zöldség-gyümölcs promóciókról. Ezzel kapcsolatban is adódik a kérdés, hogy vajon azon fogyasztók, akik még nem köteleződtek el az egészségesebb, tudatosabb életmód, táplálkozás mellett, vajon őket mennyire érték el ezek a fogyasztást népszerűsítő programok.

Pozitív, hogy e kutatásban is felszínre került, hogy a magyarok szeretik a hazai zöldséget és gyümölcsöt, és ha tehetik, ezt vásárolják, de az import még mindig komoly versenytárs a vásárlási döntéskor.

\section{5. ÖSSZEFOGLALÁs - SUMMARY}

E kutatás egy átfogó fókuszcsoportos vizsgálatsorozattal kereste a válaszokat a rendszeres zöldség-gyümölcs fogyasztás okaira, hogy láthassuk, az országosan alacsony szintű fogyasztás ellenére vannak elkötelezett rétegek, akiknek fontos, hogy megfelelő mennyiségú zöldséget és gyümölcs fogyasszanak, de nem azért, hogy eleget tegyenek bármilyen ajánlásnak is. Maguk miatt teszik, mert szeretik e termékeket, és szinte elképzelhetetlennek tartják, hogy ne fogyasszanak ezekből rendszeresen. E kutatás számos további kérdést is felvet, többek közt, hogy vajon egy termékhez vagy termékkategóriához való érzelmi kötődés hogyan alakítható ki, és mely életszakaszban valósítható meg? Az eredmények - még ha nem is reprezentatívak - elgondolkodtatóak a tekintetben, hogy szükséges-e a zöldségeket és a gyümölcsöket márkázni, és hogy a promóciós programokkal hogyan lehetne minél több fogyasztót elérni. Amit eddig sok kutató bizonyított már, az a tény most is megerősödött, magasabb iskolai végzettség és magasabb jövedelem magasabb elköteleződést mutat az egészséges életmód iránt. Az életszínvonal emelkedése hozhat életmód változást is, melynek része a rendszeres zöldség-gyümölcs fogyasztás. 


\section{IRODALOMJEGYZÉK - REFERENCES}

Alkerwi, A. - Vernier, C. - Sauvageot, N. - Crichton, G. E. - Elias, M. F.: Demographic and socioeconomic disparity innutrition: application of a novel Correlated Component Regression approach. BMJOpen. 2015. 5 (eoo6814) DOI: https://doi.org/10.1136/ bmjopen-2014-006814

Feinstein, L. - Sabates, R. - Anderson, T. M. - Sorhaindo, A. - Hammond, C.: What Are the Effects of Education on Health? Measuring the Effects of Education on Health and Civic Engagement: Proceedings of the Copenhagen Symposium - (c) OECD 2006 URL: http://www.oecd.org/education/ innovation-education/37425753.pdf (Letöltés dátuma: 2020.04.10.)

GfK: Többet költünk zöldségre és gyümölcsre. 2019. URL: https://www.haztartaspanel. hu/HU/News Reader.aspx?id=154 (Letöltés dátuma: 2020.07.25.)

Gyulavári, T. - Mitev, A. Z. - Neulinger, Á. - Neumann-Bódi, E. - Simon, J. - Szú́cs, K.: A marketingkutatás alapjai. Akadémia Kiadó, Budapest, 2014.

Hofmeister-Tóth, Á.: A fogyasztói magatartás alapjai. Akadémia Kiadó, Budapest, 2014.

Keller, T.: Fogyasztói szegmentáció, 2008. GfK-Tárki. URL: http://old.tarki.hu/ $\mathrm{hu} / \mathrm{research} /$ gazdkult/fogyasztoi szegmentacio.pdf (Letöltés dátuma: 2019.10.20.)

Kozák, Á. - Veres, E.: Társadalom és rétegződés. In: Hetesi E. - Révész B. (szerk.): "Marketing megújulás": Marketing Oktatók Klubja 20. Konferenciája. 2014. Szeged, 16-29.

KSH: A háztartások életszínvonala, 2013. URL: http://www.ksh.hu/docs/hun/xftp/ idoszaki/hazteletszinv/hazteletszinv.pdf (Letöltés dátuma: 2020.03.30.)

KSH: A háztartásokéletszínvonala, 2014. URL: https://www.ksh.hu/docs/hun/xftp/ idoszaki/hazteletszinv/hazteletszinv14. pdf (Letöltés dátuma: 2020.03.30.)
KSH: A háztartások életszínvonala, 2015. URL: https://www.ksh.hu/docs/hun/xftp/ idoszaki/hazteletszinv/hazteletszinv15. pdf (Letöltés dátuma: 2020.03.30.)

KSH: A háztartások életszínvonala, 2016. URL: https://www.ksh.hu/docs/hun/xftp/ idoszaki/hazteletszinv/hazteletszinv16. pdf (Letöltés dátuma: 2020.03.30.)

KSH: A háztartások életszínvonala, 2017. URL: https://www.ksh.hu/docs/hun/xftp/ idoszaki/hazteletszinv/hazteletszinv17.pdf (Letöltés dátuma: 2020.03.30.)

KSH: A háztartások életszínvonala, 2018. URL: https://www.ksh.hu/docs/hun/ $\mathrm{xftp} / \mathrm{idoszaki} /$ hazteletszinv/2018/ index.html\#chapter-o (Letöltés dátuma: 2020.04.15.)

KSH: Az egy főre jutó éves élelmiszerfogyasztás mennyisége jövedelmi tizedek (decilisek), régiók és a települések típusa szerint (2010-) URL: http://www. ksh.hu/docs/hun/xstadat/xstadat_ eves/i_zhco23a.html (letöltés dátuma: 2020.07.22.)

KSH: Gyorstájékoztató. Keresetek, 2019. január-szeptember. URL: https://www. ksh.hu/docs/hun/xftp/gyor/ker/ker1909. html (Letöltés dátuma: 2020.01.10.)

Lehota, J.: Marketingkutatás az agrárgazdaságban. Mezőgazda Kiadó, Budapest, 2001.

Lehota, J. - Csíkné Mácsai, É. - Rácz, G.: Az egészségtudatos élelmiszer-fogyasztói magatartás értelmezése a LOHAS koncepció alapján. Táplálkozásmarketing. 2014. 1 (1-2) 39-46. DOI: https://doi. org/10.20494/TM/1/1-2/4

Malhotra, N. K.: Marketingkutatás. Akadémia Kiadó, Budapest, 2009.

Malota, E. - Gyulavár, T. - Bogáromi, E.: „Az vagy, amit megeszel”. A hazai fogyasztók egészséges táplálkozással kapcsolatos percepciói és attitüdjei. Vezetéstudomány. 2019. 5 (1) 8088. DOI: https://doi.org/10.14267/ VEZTUD.2019.01.08

Rácz, G.: Az értékek változásának és a fenntartható fejlődés trendjének hatása a hazai élelmiszerfogyasztásra. Doktori értekezés. Gödöllő, 2013. 
Róbert, P.: Osztálylétszám, 2014. GfK-MTA. URL: https://politikatudomany.tk.mta. hu/uploads/files/Osztalyletszam2014_ MTATK.pdf, https://politikatudomany. tk.mta.hu/uploads/files/retegek leirasa__nehany_fontos_adat.pdf (Letöltés dátuma: 2019.10.15.)

Szakály, Z. - Pető, K. - Popp, J. - Jasák, H.: A LOHAS szegmens mérete és jellemzői Magyarországon. Táplálkozásmarketing. 2015. 2 (1) 11-30. DOI: https://doi. org/10.20494/TM/2/1/2

Szakály,Z.-Szabó,S. -Jasák,H.-Szente, V. - Kiss, M.: A személyes értékek hatása az egészségmagatartás változására és a tudatos élelmiszervásárlásra. Táplákozásmarketing. 2014. 1 (1-2) 57-71. DOI: https://doi.org/10.20494/TM/1/12/9

Szakály, Z. - Szigeti, O. - Szente, V. - Polereczki, Zs.: Funkcionális élelmiszerek marketingje és piacvezérelt fejlesztése. Kaposvári Egyetem TÁMOP 4.2.2/B-10/1 kutatási program eredménye. In.: Szakály, Z. (szerk.): Élelmiszermarketing. Akadémia Kiadó, Budapest, 2013 .
Thiele, S. - Peltner, J. - Richter, A. Mensink, G. B. M.: Food purchase patterns: empirical identification and analysis of their association with diet quality, socio-economic factors, and attitudes. Nutrition Journal. 2017. 16 (1) 69 DOI: https://doi.org/10.1186/s12937017-0292-z

Tamus, A.: A fogyasztói magatartás tényezői a gyümölcsfélék piacán. Doktori értekezés. Gödöllő. 1998.

Törőcsik, M. - Szúcs, K. - Nagy, Á. - Lázár, E.: Életstíluscsoportok Magyarországon a digitalizáció korában. Életstílus-kutatások és a marketing. Replika. 2019. 2 (111) 63-86. DOI: https://doi.org/10.32564/111.5

Vetőné Mózner, Zs.: Az élelmiszerfogyasztás szerkezete és környezeti hatása Magyarországon. Marketing\&Menedzsment. 2014. 3 57-70.

WHO: Promoting fruit and vegetable consumption around the world. URL: https://www.who.int/ dietphysicalactivity/fruit/en/ (Letöltés dátuma: 2019.10.10.)

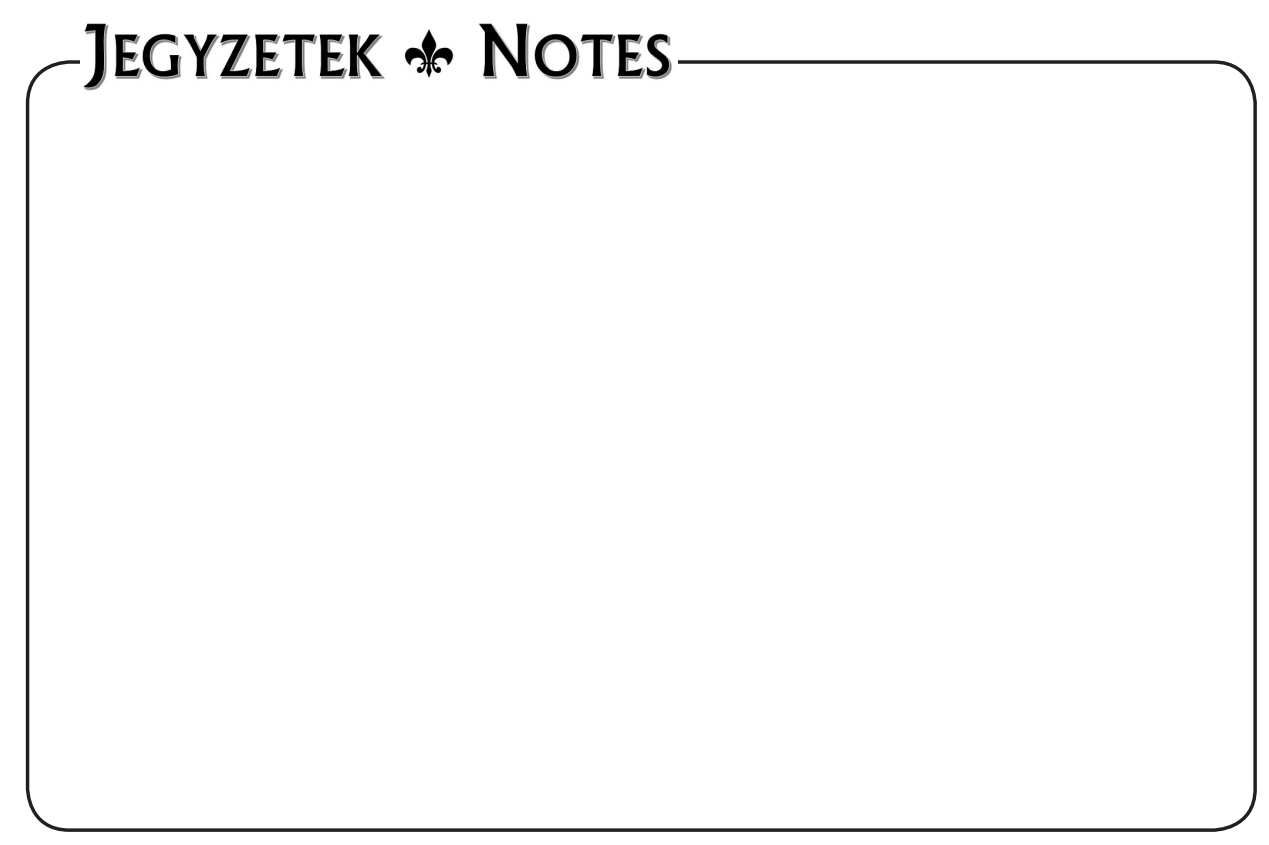

